\title{
旧浜松鉄道病院建物破壊試 験（乞の3 耐震壁試験）
}

正会員平 井利一*（代表）

§1. 試験体概要 第1図に示すように建物の張間方向 ラーメンの半分、1スパンゼけ各階スラブおよび梁を切 断し、他の部分を反力として水平加力ができるように $100 \mathrm{t}$ ジャッキを取付けてある。柱梁の断面および配筋 は張間試験体と同じであるが、1 階には厚さ $12 \mathrm{~cm}$ の 鉄筋コンクリート壁がある。この試験では壁そのものの 破壊よりも、地盤を含めた全体の系の耐力剛性を知るた め地中梁も切断した。なお廊下側のフーチングは反力側 と一体になっているが工事の都合上切断できなかった。

§2. 試験方法 張間試験之同様各階床水平変位、基礎 の沈下浮上り、および節点部分の傾斜測定並びに自由振 動試験を行なった。試験順序は設計荷重、計算降代荷重、 実降伏荷重、大変形、破壊の順に静的水平力試験を行な い、各試験の間にその都度自由振動試験を行なった。

\section{§3. 試験結果}

屋階加力時の屋階 相対変形抢よび 2 階 加力時の 2 階相対変 形を第 2 図に示す。 屋階加力の際、加力 装置の不備のため初 めのうち圧力計が不 安定な值を示した。

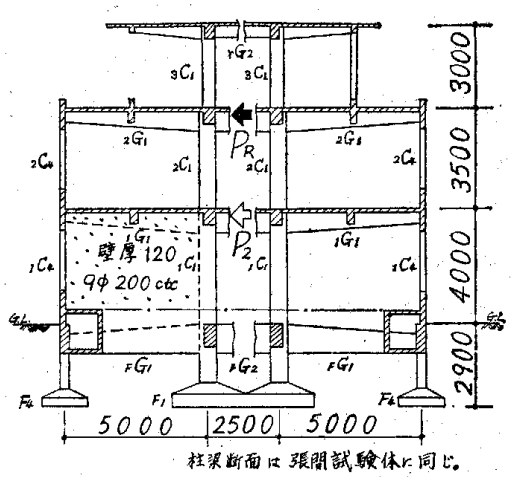
そのため第 2 図の一 部には補正した推定 值を破線で示してあ る。図には弾性岡性

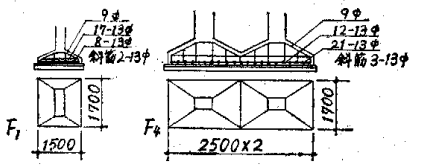

第 1 図 耐震壁試験体スフルトン および終局強度の計算值が併記してあるが、とれは ${ }_{c} E=$ $210 \mathrm{t} / \mathrm{cm}, G=90 \mathrm{t} / \mathrm{cm}^{2},{ }_{c} f_{c}=300 \mathrm{~kg} / \mathrm{cm}^{2},{ }_{s} f_{y}=3.3 \mathrm{t} / \mathrm{cm}^{2}$, $A_{w}=12 \times 400=4800 \mathrm{~cm}^{2}, \tau_{y}=15 \mathrm{~kg} / \mathrm{cm}^{2}$ と仮定して計算 した值である。第3 図は終局状態における刍裂発生状沇 を示したものである。壁の中央に、ほぼ垂直に初龟裂が 入っていたため剪断亀裂は内側半分化のみ発生してい る。廊下中央で梁を切断したので、2 階のラーメンは柱 頭部で大梁下端筋のすべりを生じた。このため刍裂は節 点に集中して生じたがその割にかなり大きな靯性を示し た。又、柱脚には曲げによる圧壞が見られた。第 4 図は

* 本研究は次のメンバーによる

東京大学助教授．工博 梅村 魁・同、工博 大沢 胖・同 大学院、廖 慧明・国鉄波阜工事局建築課長、松島勇雄・国 鉄鉄道技術研究所建築研究室長、井原道継・同、建築研究室 主任研究員、上田周明 - 同、建築研究空研究員、田村光男 熊谷組技術研究所員、○平井利一
2 階加力時にお

ける 2 階の変位 をスウェー、ロ ッキング、たわ みに分け、試験 ごとにその割合 を示したもので ある。この図か ら分るように、 スウェーとロッ キングによる変 位が90 95\%を 占め非常に大き い。動的武験の 結果は、固有周 期 $0.13 \sim 0.20$ 秒、減衰常数 $0.025 \sim 0.063 \omega$ 範囲にあるが破 罱状沅あるいは 振幅己あまり関 係なく、まちま ちな値を示して いる。最後に、 本試験に当り特 別の理解之援助 を賜わりました 静岡幹線工事局 長坂本㖽 雄、岥㚖工 事局長市嶋 武視の両氏 を始め本試 験に協力心 ただいた静 岡幹線工事 局、岥皁工 事局、静岡 鉄道管理局

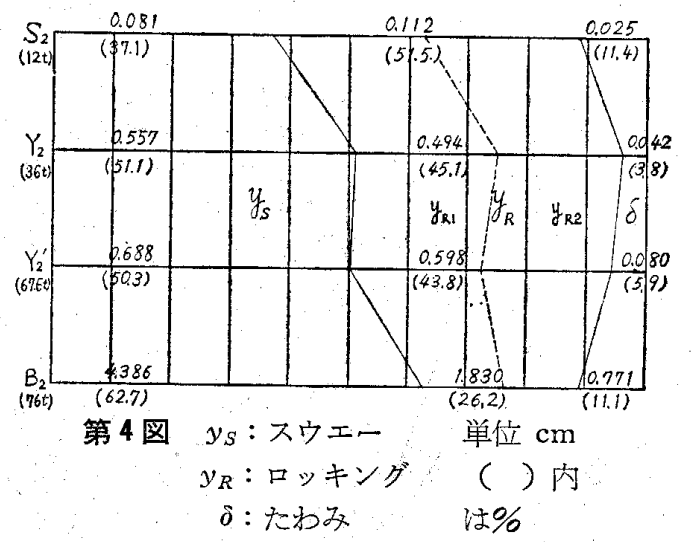

鉄道技研建築研究室、東京大学武藤研究室大学院、熊谷 組技術研究所、同浜松作業所の諸氏に厚く謝意を表す る。

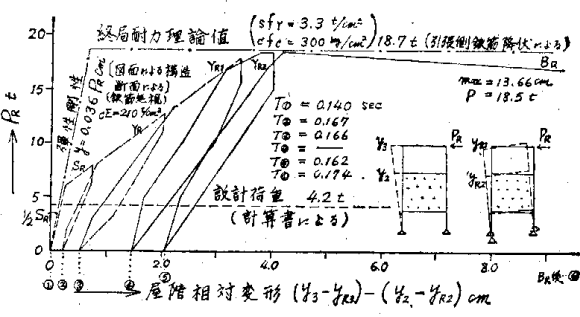

第 2 図の上

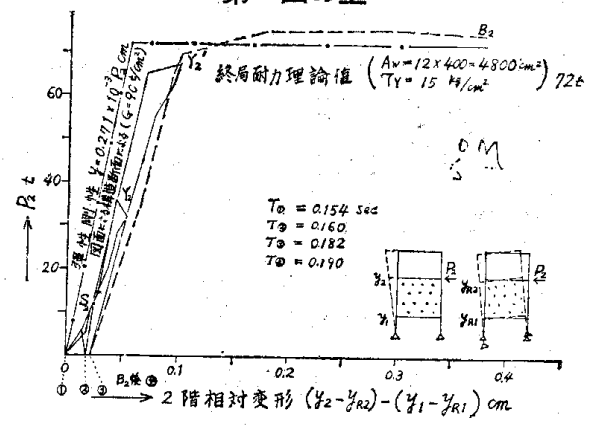

第 2 図 荷重変形曲線

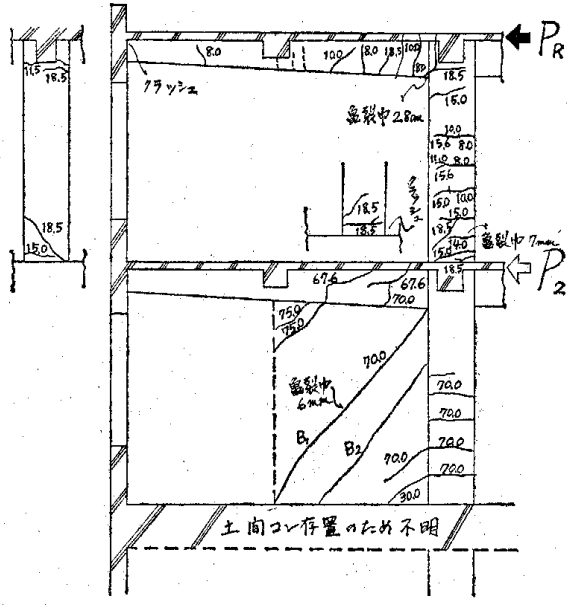

第 3 図 重裂図 